\title{
Mutant PI/GLO Homolog Confers the Hose-in-hose Flower Phenotype in Kurume Azaleas
}

\author{
Kyeong-Seong Cheon, Akira Nakatsuka and Nobuo Kobayashi* \\ Faculty of Life and Environmental Sciences, Shimane University, Matsue 690-8504, Japan
}

To analyze hose-in-hose flowers of Kurume azaleas, floral morphologies and homeotic MADS genes were investigated in single and hose-in-hose cultivars. In floral morphological analysis, single flowers are comprised of four whorls of floral organs: sepals, petals, stamens, and carpels. Hose-in-hose flowers, in contrast, produced petaloid sepals instead of sepals in the first whorl. Based on molecular analysis, we isolated PISTILLATA (PI)/GLOBOSA (GLO) homologs in the hose-in-hose flower cultivar 'Kirin' and analyzed their expression in single flower and hose-in-hose flower cultivars. The mRNA sequences of two RoPI genes, RoPI-1 and RoPI-2, differed in terms of a 6 bp deletion. Based on genomic analysis, an insertion sequence was found in the second intron of RoPI-1 in hose-in-hose flowers. These RoPI genes were mainly expressed in the second and third whorls of single flowers, whereas these genes were expressed in all whorls of hose-in-hose flowers. These results suggest that the up-regulation of RoPI-1 expression contributed to the petaloid sepal formation of hosein-hose flowers of Kurume azaleas.

Key Words: GLOBOSA, homeotic genes, Rhododendron, transposable element.

\section{Introduction}

Japanese evergreen azaleas (Rhododendron spp.) are one of the most popular garden plants and an important genetic resource for azalea breeding as ornamental shrubs or pot azaleas. Many wild individuals and hundreds of azalea cultivars have been selected by horticulturists from natural populations of indigenous evergreen azalea species and their hybrids since the Edo era (1603-1867) (Kobayashi et al., 2003). Among the evergreen azaleas, the Kurume cultivars are particular favorites in Japan as well as other countries (Wilson and Rehder, 1921). In Kurume city, towards the end of the Edo era, Mr. Sakamoto (a retainer of the Kurume feudal clan) made good progress in the breeding of Rhododendron obtusum, and his work may well have laid the foundation for today's Kurume azalea breeding (Kobayashi et al., 2003; Tamura et al., 1989; Wilson and Rehder, 1921). After the advancement of artificial breeding techniques in the Meiji period (19th century),

Received; December 26, 2015. Accepted; February 24, 2016.

First Published Online in J-STAGE on April 8, 2016.

This study was supported by a Grant-in-Aid for Scientific Research (KAKENHI Nos. 26292017 and 23241076) from the Japan Society for the Promotion of Science (JSPS).

* Corresponding author (E-mail: nkobayashi@life.shimane-u.ac.jp).
Kurume azalea cultivars were extensively developed and more than 300 cultivars exist at present (Kobayashi et al., 2003; Tamura et al., 1989).

Kurume azalea cultivars have several floral shape mutants. One popular mutant is the "hose-in-hose" flower, which is called "Futae-zaki" in Japanese. In hose-in-hose flowers, sepals of azaleas are converted to petaloid sepals; the organ of the first whorl is more similar in appearance to petals than to sepals (Heursel, 1976). In genetic analysis of the 'Kirin' azalea, the hose-in-hose flower $(\mathrm{H})$ is dominant to the single flower (h), and hose-in-hose flowers are heterozygous ( $\mathrm{Hh})$ (Heursel, 1976; Sakata and Hashimoto, 2004). Homozygous $(\mathrm{HH})$ hose-in-hose flowers do not exist, because a cross between hose-in-hose flowers was unsuccessful (Heursel, 1976). Although it has been reported that the hose-in-hose phenotype in azaleas is controlled by a single locus (Miyazawa, 1922), molecular analysis of hose-in-hose flowers in azaleas has not yet been reported.

Floral organ formations were first described in the model angiosperms Arabidopsis thaliana and Antirrhinum majus, leading to the proposal of the ABC model of floral development (Coen and Meyerowitz, 1991; Weigel and Meyerowitz, 1994). Based on this model, the A-function genes alone produce sepals in the first whorl and the combination of A- and B-function 
genes specifies petal formation in the second whorl. The combination of B- and C-function genes specifies stamen formation in the third whorl and the $\mathrm{C}$ function genes alone specify carpels in the fourth whorl. In Arabidopsis, A class genes are represented by APETALA1 and APETALA2, B class genes comprise APETALA3 (AP3) and PISTILLATA (PI), and the C class gene is $A G A M O U S(A G)$. The model genes $P I$ and GLOBOSA (GLO, which is the PI homolog from Antirrhinum) interact as heterodimers with $A P 3$ and DEFICIENS (DEF, which is the AP3 homolog from Antirrhinum) to specify petal and stamen formation (Krizek and Meyerowitz, 1996a; Riechmann and Meyerowitz, 1997).

Petaloid sepals are explained by a modified $A B C$ model in which $\mathrm{B}$ class gene expression is extended into the first whorl of Tulipa gesneriana (Kanno et al., 2003), Habenaria (Pecteilis) radiata (Kim et al., 2007, 2010), and the Orchidaceae (Kanno and Kim, 2009). Moreover, in transgenic plants, the PI/GLO gene alone is sufficient to convert the first whorl to petaloid sepals (Davies et al., 1996; Krizek and Meyerowitz, 1996a). In contrast to other plants, floral form mutations in azaleas have been poorly investigated at the molecular level. After initiation of floral bud formation, RpAP3 expression was increased in the floral buds of Rhododendron $\times$ pulchrum (Cheon et al., 2011), and RkAG was overexpressed in the second whorl of staminoid-petaled cultivars of R. kaempferi (Tasaki et al., 2012).

In this study, to analyze hose-in-hose flowers, we investigated flower morphology of petal and petaloid sepals. To further characterize hose-in-hose flowers at the molecular level, we focused on the azalea $P I / G L O$ homolog and investigated the relationship between this gene and the hose-in-hose flower in Kurume azaleas.

\section{Materials and Methods}

\section{Plant materials and sampling}

Single flower cultivars 'Wakakaede' and 'Oinomezame' and hose-in-hose flower cultivars 'Kirin' and 'Kurenoyuki', were obtained from the azalea resources collection of the Plant Breeding Laboratory of the Faculty of Life and Environmental Sciences of Shimane University (Fig. 1). To investigate flower morphology, the abaxial epidermal cells of sepals and petals in 'Wakakaede' and 'Kirin' were analyzed by scanning electron microscopy (SEM; HITACHI TM3000, Tokyo, Japan). For total RNA extraction, each floral organ (sepals, petals, stamens, and carpels) was sampled from 10-20 flowers in all plant materials because the sepals of single flowers are very small. For genomic DNA (gDNA) extraction, 4-5 leaves were sampled from all plant materials. These samples were immediately frozen in liquid nitrogen and stored at $-80^{\circ} \mathrm{C}$ until the extraction for total RNA and gDNA.

\section{Isolation of the PI/GLO homolog from mRNA of hose- in-hose 'Kirin'}

Total RNA was extracted from each floral organ of all plant materials using an RNeasy plant mini kit (Qiagen, Hiden, Germany). The RNA extracts were then treated with RQ1-RNase-free DNase (Promega, Madison, MI, USA) to remove gDNA from the samples. Then, cDNA templates were synthesized from the DNase-treated total RNA (1 $\mu \mathrm{g})$ with ReverTra-Ace (Toyobo, Osaka, Japan). To isolate the PI/GLO homolog from the hose-in-hose flower 'Kirin', the amplifications were carried out with petal-derived cDNA and primers (forward 5'-ATGGGGAGGGGAAAGATAG AG-3' and reverse 5'-GTGCACAAATTAACCAAGTT
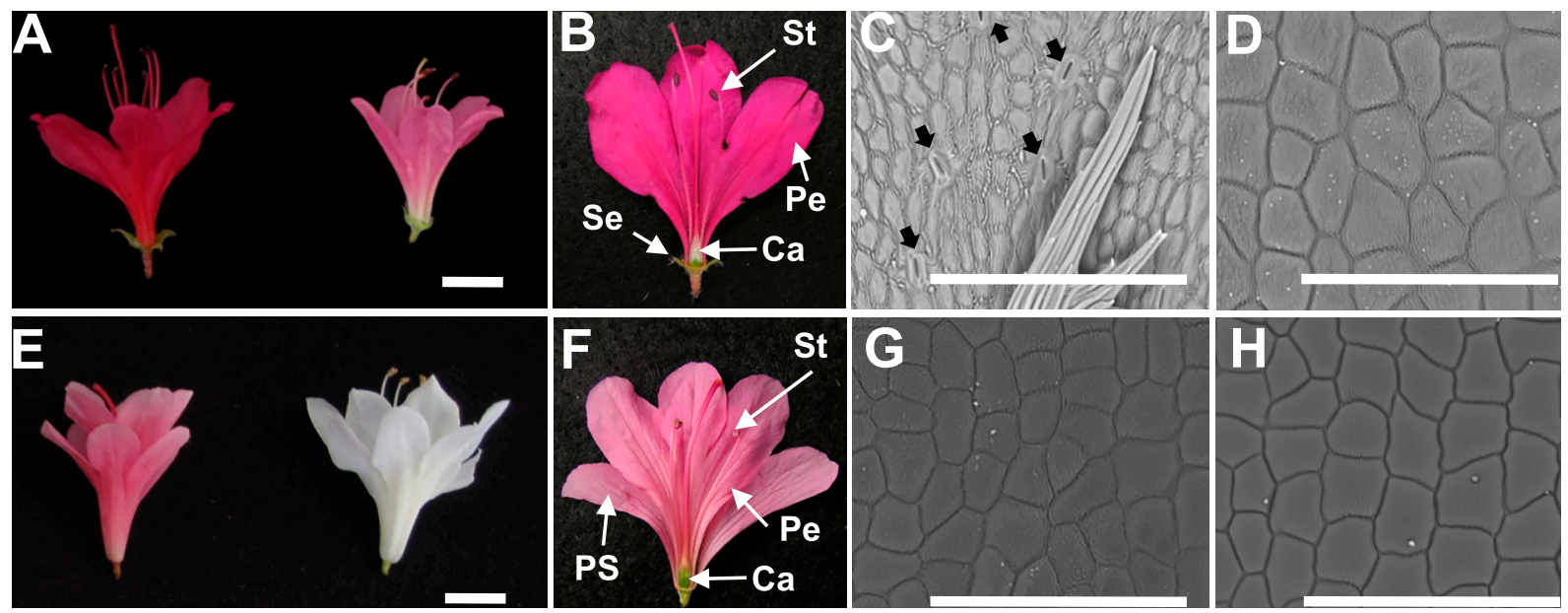

Fig. 1. Flower morphology of single and hose-in-hose flowers in Kurume azaleas. A: Photo of single flowers, 'Wakakaede' (left) and 'Oinomezame' (right). B: Photo of floral organs in 'Wakakaede'. C and D: Scanning electron microscope (SEM) images of an abaxial sepal (C) and petal (D) in 'Wakakaede'. E: Photo of hose-in-hose flowers, 'Kirin' (left) and 'Kurenoyuki' (right). F: Photo of floral organs in 'Kirin'. G and H: SEM images of an abaxial petaloid sepal $(\mathrm{G})$ and petal $(\mathrm{H})$ in 'Kirin'. Pe: petal, Se: sepal, St: stamen, Ca: carpel, PS: petaloid sepal. Closed arrows indicated stomata. Bars indicate $1 \mathrm{~cm}(\mathrm{~A}$ and $\mathrm{E})$ and $250 \mu \mathrm{m}(\mathrm{C}, \mathrm{D}, \mathrm{G}$, and $\mathrm{H})$. 
TT TTACCTT-3'), which were designed from the start codon to the $3^{\prime}$ untranslated region (UTR) sequences in $\operatorname{RrPI}$ (AB639033). Each $10 \mu \mathrm{L}$ reaction mixture contained $1 \times$ Ex-Taq buffer, $200 \mu \mathrm{M}$ dNTPs, $0.2 \mu \mathrm{M}$ of each primer, $0.25 \mathrm{U}$ Ex-Taq (TaKaRa Bio, Shiga, Japan), and $25 \mathrm{ng}$ cDNA template. Cycle conditions were as follows: preheating at $94^{\circ} \mathrm{C}$ for $1 \mathrm{~min} ; 35 \mathrm{cy}-$ cles of denaturation at $94^{\circ} \mathrm{C}$ for $30 \mathrm{~s}$, annealing at $62^{\circ} \mathrm{C}$ for $30 \mathrm{~s}$, and extension at $72^{\circ} \mathrm{C}$ for $30 \mathrm{~s}$; and final extension at $72^{\circ} \mathrm{C}$ for $1 \mathrm{~min}$. The amplified fragments were cloned into the pGEM-T easy vector (Promega) and E. coli DH5a competent cells (Nippon Genetics Co., Tokyo, Japan) and sequenced using the BigDye Terminator version 3.1 Cycle Sequencing Kit (Applied Biosystems, Foster City, CA, USA) and ABI 3130 genetic analyzer (Applied Biosystems) after plasmid DNA extraction by a FastGene Plasmid Mini kit (Nippon Genetics Co.). The nucleotide sequences and deduced amino acid sequences of the isolated PI/GLO homolog
mRNA were aligned by the BLASTx function in Genetyx ver. 12 (Software Development Co., Tokyo, Japan).

Expression analysis of Kurume azalea PI/GLO homo$\log$

Semi quantitative reverse transcription polymerase chain reaction (semi-qRT-PCR) and reverse transcription quantitative polymerase chain reaction (RT-qPCR) were performed to examine the expression levels of the $\mathrm{B}$ and $\mathrm{C}$ class genes in each floral organ of all plant materials. In the semi-qRT-PCR assay, each $20 \mu \mathrm{L}$ reaction mixture contained $1 \times$ Ex-Taq buffer, $200 \mu \mathrm{M}$ dNTPs, $0.2 \mu \mathrm{M}$ of each azalea RpAP3 (AB598826; forward 5'TATGAGAAAATGCAAGAGCAC-3' and reverse 5'GGCTAATATACCGCGGCCTC-3', Tasaki et al., 2012), RoPI (forward 5'-CTGGAAACTGGCCTTGC-3' and reverse 5'-GGCATCTGGGGCTGGTA-3', Fig. 2A), and $R k A G$ (AB639031, forward 5'-TGCCATCATCCC

A
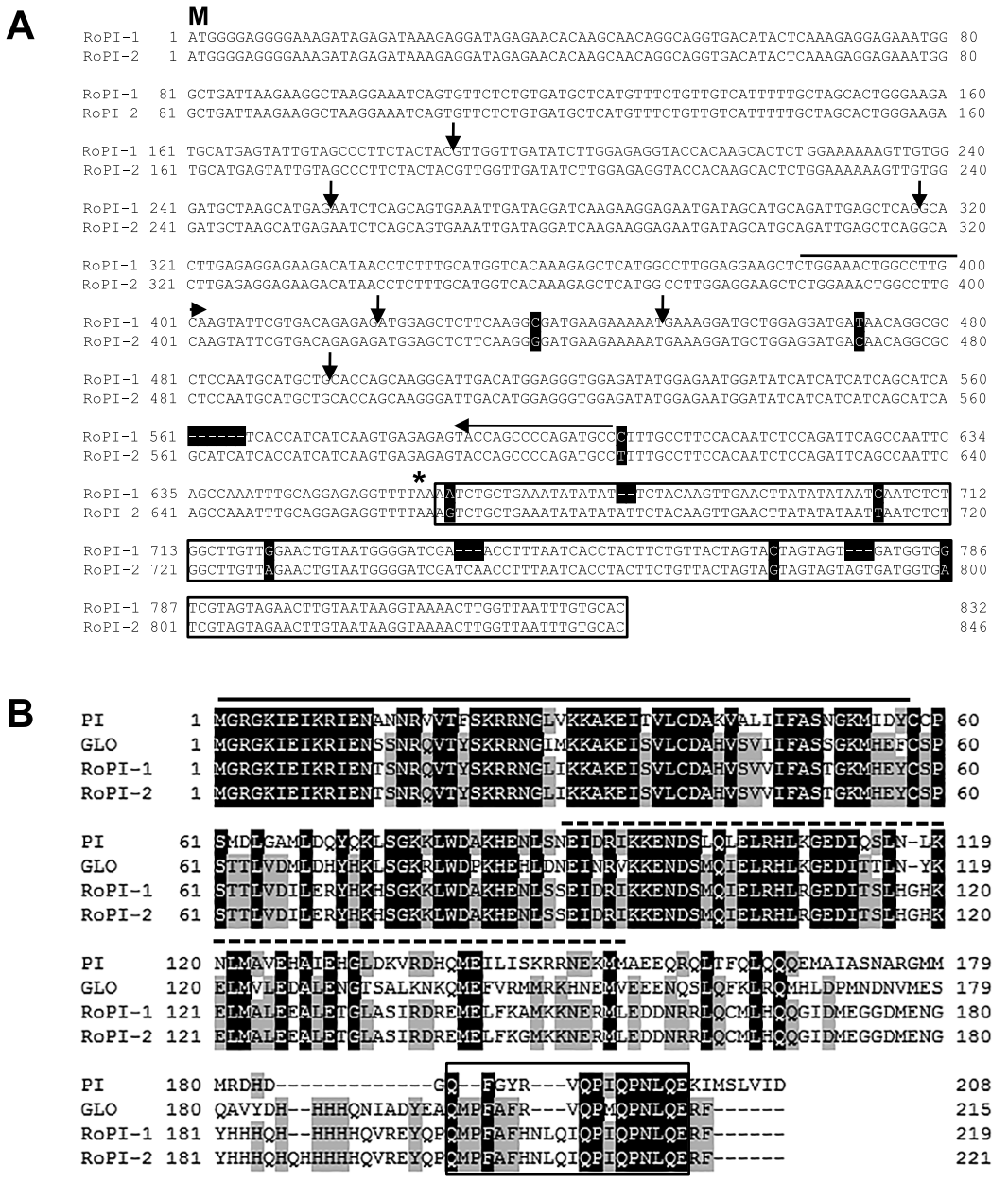

PI-Motif

Fig. 2. Isolation of RoPI genes from 'Kirin'. A: Comparison of RoPI-1 and RoPI-2 mRNA sequences from the start codon to 3' UTR region. The symbol $\mathrm{M}$ and asterisk indicate the start and stop codon, respectively. Black and open boxes indicate different sequences and the 3 ' UTR region in RoPI-1 and RoPI-2 sequences, respectively. Horizontal and vertical arrows indicate the primer region and direction for expression analysis and intron regions, respectively. B: Multiple sequence alignment of Arabidopsis PI and Antirrhinum GLO and the deduced amino acid sequences for RoPI-1 and RoPI-2. Solid line, dotted line, and open boxes indicate the MADS domain, K domain, and PI-motif, respectively, among Arabidopsis PI (AED92817), Antirrhinum GLO (Q03378), and deduced RoPI amino acid sequences. 
ATGATCAT-3' and reverse 5'-TTGTCCAGCAACAA CATACT-3', Tasaki et al., 2012) primer, 0.5 U Ex-Taq (TaKaRa Bio), and $1 \mu \mathrm{L} 30 \times$ diluted cDNA templates. Especially, a primer pair was used for both RoPI-1 and RoPI-2, because the RoPI-1 sequence was very similar to RoPI-2. The reaction conditions of PCR were as follows: preheating at $94^{\circ} \mathrm{C}$ for $1 \mathrm{~min} ; 35$ cycles of denaturation at $94^{\circ} \mathrm{C}$ for $30 \mathrm{~s}$, annealing at $54^{\circ} \mathrm{C}(R p A P 3$ and $R k A G), 60^{\circ} \mathrm{C}(R o P I)$, and $52^{\circ} \mathrm{C}(A C T I N)$ for $30 \mathrm{~s}$, and extension at $72^{\circ} \mathrm{C}$ for $30 \mathrm{~s}$; and final extension at $72^{\circ} \mathrm{C}$ for $5 \mathrm{~min}$. The amplified PCR products were separated by electrophoresis on $1 \%$ agarose gel (Nippon Genetics Co.) in $0.5 \times \mathrm{TBE}$ buffer at $100 \mathrm{~V}$ for $30 \mathrm{~min}$. The cDNA samples were normalized to azalea ACTIN amplicons (AB610421; forward 5'-AGCAATGTATGTT GCTATCC-3' and reverse 5'-TGATCGAGTTGTAGG TAGTC-3') for semi-qRT-PCR assay.

In addition, to investigate $P I / G L O$ homolog expression in first and second whorls, the RT-qPCR assay was performed in a $20 \mu \mathrm{L}$ reaction mix containing $1 \mu \mathrm{L}$ of $10 \times$ diluted cDNA templates, $10 \mu \mathrm{L}$ of SYBR Premix Ex-Taq II (TaKaRa Bio), and $0.25 \mu \mathrm{M}$ of each ACTIN (AB610421; forward 5'-TCTTGATCTTGCTGGTCG TG-3' and reverse 5'-GGGCATCTGAATCTCTCA GC-3'), Histone H3 (AM932886; forward 5'-GAA ACTCCCATTCCAGAGGCT-3' and reverse 5'-GCA TGGATGGCACAGAGGTT-3'), and the above RoPI primers. Each RT-qPCR assay was conducted using a Thermal Cycler Dice Real-Time System (TaKaRa Bio) with an initial denaturation of $30 \mathrm{~s}$ at $95^{\circ} \mathrm{C}$, followed by 40 cycles of $5 \mathrm{~s}$ at $95^{\circ} \mathrm{C}$ and $30 \mathrm{~s}$ at $60^{\circ} \mathrm{C}$. Three technical replicates were analyzed for each cDNA sample. Quantitation was performed by using the difference in the threshold cycle values $(\Delta \mathrm{Ct})$ between the two samples (the target genes and the reference genes, both azalea ACTIN and Histone H3) to calculate the relative amounts of the template present. The value of the relative expression was calculated as the standard using the maximum value for the RoPI gene, and the mean and standard error (SE) were calculated from the value of the relative expression (Cheon et al., 2011).

Isolation of the PI/GLO homolog and insertion sequence from 'Kirin' $g D N A$

The gDNA was extracted from leaves in each plant sample using the modified CTAB method (Kobayashi et al., 1998). For azalea, PI/GLO homolog isolation from 'Kirin' gDNA, the 5' upstream region of $P I / G L O$ homolog in 'Kirin' gDNA was identified by inverse PCR (Ochman et al., 1988). A restriction enzyme, NheI, was used to digest $500 \mathrm{ng}$ gDNA and the digested gDNA fragments were self-ligated with $\mathrm{T} 4$ ligase (Promega) overnight. Inverse PCR was performed in $10 \mu \mathrm{L}$ reaction mixtures containing $1 \mu \mathrm{L}$ self-ligated gDNA, $1 \times$ Ex-Taq buffer, $200 \mu \mathrm{M}$ dNTPs, $0.25 \mathrm{U}$ ExTaq (TaKaRa Bio), and primers, first PCR (forward 5'CAGGTGACATACTCAAAGACCACA-3' and reverse
5'-GCTTGTGTTCTCTATCCTCTTTA-3') and second PCR (forward 5'-GAGAAATGGGCTGATTAAGAAG GC-3' and reverse 5'-ATCTCTATCTTTCCCCTCCC CAT-3') primers. The reaction conditions of nested PCR were as follows: preheating at $94^{\circ} \mathrm{C}$ for $5 \mathrm{~min} ; 35 \mathrm{cy}-$ cles of denaturation at $94^{\circ} \mathrm{C}$ for $30 \mathrm{~s}$, annealing at $55^{\circ} \mathrm{C}$ (1st PCR) $/ 60^{\circ} \mathrm{C}$ (2nd PCR) for $30 \mathrm{~s}$, and extension at $72^{\circ} \mathrm{C}$ for $4 \mathrm{~min}$; and final extension at $72^{\circ} \mathrm{C}$ for $10 \mathrm{~min}$. The amplified fragments were sequenced as described above.

Subsequently, to isolate the azalea $P I / G L O$ homolog from 'Kirin' gDNA PCR amplification, from the 5' upstream to 3' UTR region, was performed in $20 \mu \mathrm{L}$ reaction mixtures containing $20 \mathrm{ng}$ gDNA, $1 \times$ PrimeSTAR GXL polymerase buffer, $200 \mu \mathrm{M}$ dNTPs, $0.5 \mathrm{U}$ PrimeSTAR GXL polymerase (TaKaRa Bio), and $0.2 \mu \mathrm{M}$ of each primer. The primers were designed on the 5' upstream and 3' UTR regions (forward 5'GTGCAATTACAGGGGGATGAAGGAG-3' and reverse 5'-GTGCACAAATTAACCAAGTTTTACCTT3'). The conditions for PCR amplification were as follows: preheating at $98^{\circ} \mathrm{C}$ for $5 \mathrm{~min} ; 35$ cycles of denaturation at $98^{\circ} \mathrm{C}$ for $10 \mathrm{~s}$, annealing at $60^{\circ} \mathrm{C}$ for $15 \mathrm{~s}$, and extension at $68^{\circ} \mathrm{C}$ for $10 \mathrm{~min}$; and final extension at $72^{\circ} \mathrm{C}$ for $20 \mathrm{~min}$. A-overhangs were created on the amplified fragments $\left(0.25 \mathrm{U}\right.$ Ex-Taq at $72^{\circ} \mathrm{C}$ for $\left.30 \mathrm{~min}\right)$ in order to perform TA-cloning. The treated fragments were cloned into E. coli HST08 Premium Competent Cells (TaKaRa Bio) with the TOPO-XL PCR cloning kit (Invitrogen, Carlsbad, CA, USA), and the clones were sequenced as described above. After sequencing analysis, the isolated sequences from the 'Kirin' gDNA were compared to normal and mutant gene sequences using Genetyx ver. 12 (Software Development Co.).

\section{Investigation of azalea PI/GLO mutant allele in Kurume azaleas}

To analysis the mutant allele of $P I / G L O$ homolog in Kurume azalea cultivars, PCR amplifications were carried out on gDNA of all plant materials. The PCR was performed in $20 \mu \mathrm{L}$ reaction mixtures containing $20 \mathrm{ng}$ gDNA, $1 \times$ Ex-Taq buffer, $200 \mu \mathrm{M}$ dNTPs, $0.25 \mathrm{U}$ ExTaq (TaKaRa Bio), and $0.2 \mu \mathrm{M}$ of each primer. Four primers were used: P1 (5'-TGGAAAAAAGTTGTGGG ATG-3'), P2 (5'-TGAGCTCAATCTGCATGCTA-3'), P3 (5'-CCACGCAAAATCAAAAAGAG-3'), and P4 (5'-GCCAATATTGGGGGTAAAAGT-3') (Fig. 5). The conditions of PCR amplification were as follows: preheating at $94^{\circ} \mathrm{C}$ for $1 \mathrm{~min} ; 35$ cycles of denaturation at $94^{\circ} \mathrm{C}$ for $30 \mathrm{~s}$, annealing at $60^{\circ} \mathrm{C}$ for $30 \mathrm{~s}$, and extension at $72^{\circ} \mathrm{C}$ for $30 \mathrm{~s}$; and final extension at $72^{\circ} \mathrm{C}$ for $1 \mathrm{~min}$. The amplified PCR products were confirmed by electrophoresis on $1 \%$ agarose gel (Nippon Genetics Co.) in $0.5 \times \mathrm{TBE}$ buffer at $100 \mathrm{~V}$ for $30 \mathrm{~min}$. 


\section{Results}

Floral morphology of single and hose-in-hose flowers in Kurume azaleas

To characterize hose-in-hose flowers from Kurume azaleas, we analyzed sepal and petal morphologies in single and hose-in-hose flowers (Fig. 1). Three normal floral organs - petals, stamens, and carpels - were observed from both single and hose-in-hose flowers (Fig. 1A, B), whereas petaloid sepals instead of sepals in the first whorl were observed only in hose-in-hose flowers (Fig. 1E, F). A higher number of stomata on the abaxial surface of the first whorl were observed for the single flower cultivar 'Wakakaede' (Fig. 1C) than for the hose-in-hose flower cultivar 'Kirin' (Fig. 1G). Moreover, the epidermal cell sizes of the first whorl in hose-in-hose flowers were larger than in single flowers (Fig. 1C, G). However, the epidermal cells on the abaxial surface showed almost the same arrangements and sizes in the first and second whorl of 'Kirin' and the second whorl of 'Wakakaede' (Fig. 1D, G, H). These results indicate that sepals convert to petaloid sepals in the first whorl of hose-in-hose flowers.

\section{Isolation of azalea PI/GLO homologs from hose-in- hose flowers}

To analyze petaloid sepals from the first whorl of hose-in-hose flowers, azalea $P I / G L O$ homologs were isolated from hose-in-hose 'Kirin' (Fig. 2). The isolated PI/GLO homologs were termed RoPI-1 (832 bp, DDBJ accession number LC107398), and RoPI-2 (846 bp, DDBJ accession number LC107399); RoPI-1 shared 98\% nucleotide sequence identity with RoPI-2 in the coding region. Differences between the two genes were shown in eight sequences, including a difference of $6 \mathrm{bp}$ in exon 7 and 8 bp in 3' UTR (Fig. 2A). The deduced amino acid sequences showed $98 \%$ identity between RoPI-1 and RoPI-2. Comparison of published amino acid sequences with those of both RoPI-1 and RoPI-2 showed 63\% identity with GLO of Antirrhinum and 55\% identity with Arabidopsis PI. The deduced amino acid sequences of the MADS-domain, K-domain, and PI motif encoded by RoPI-1 and RoPI-2 were homologous to those in GLO and PI (Kramer et al., 1998; Krizek and Meyerowitz, 1996b) (Fig. 2B).

Expression analysis of $B$ and $C$ class genes by semi$q R T-P C R$ and $R T-q P C R$

To investigate the relationship between petaloid sepals and homeotic genes, semi-qRT-PCR and RT-qPCR were performed on cDNA from each floral organ (Fig. 3). In a semi-qRT-PCR assay of single flowers, RoPI was mainly expressed in the second and third whorls, whereas $R p A P 3$ was expressed in all whorls and $R k A G$ was mainly expressed in the third and fourth whorls. However, in hose-in-hose flowers, both RoPI and $R p A P 3$ genes were expressed in all whorls, and
A

SF



B

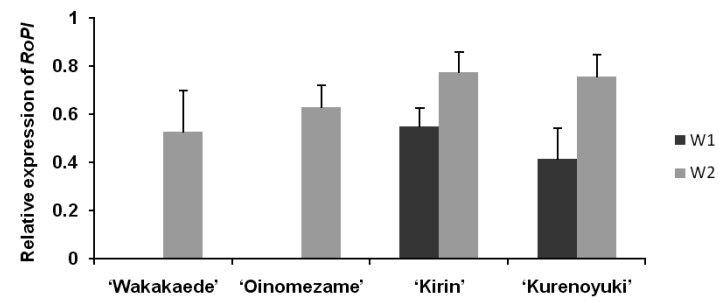

Fig. 3. Expression analysis of homeotic MADS-box genes in single (SF) and hose-in-hose flowers (HF). A: Expression analysis using semi-qRT-PCR in whorl 1, 2, 3, and 4 (W1-4, respectively). Azalea $A C T I N$ was used as an internal control. NC indicates negative control. B: Expression analysis of RT-qPCR in whorl 1 and 2 (W1 and 2, respectively). Azalea ACTIN and HistonH3 were used as an internal control. The data represent the mean and standard errors obtained from three technical replicates.

$R k A G$ was mainly expressed in the third and fourth whorls. In each floral organ of 'Kirin' especially RoPI-1 (lower band) and RoPI-2 (upper band) were detected at almost the same level (Fig. 3A). Moreover, when an RT-qPCR assay was done in order to analyze RoPI expression in first and second whorls, the gene expressions showed almost the same pattern in the second whorl of all plant materials, whereas the gene expressions were highly divergent between hose-in-hose flowers and single flowers in the first whorl (Fig. 3B).

\section{Analysis of RoPI genes from 'Kirin' $\mathrm{gDNA}$}

To understand how to increase RoPI gene expression in the first whorl of hose-in-hose flowers, we isolated RoPI genes from 'Kirin' gDNA. In PCR amplification, a band of approximately $7 \mathrm{~kb}$ was detected from gDNAs of single flower types, and two bands, approximately $6 \mathrm{~kb}$ and $8 \mathrm{~kb}$, were amplified from gDNA of hose-in-hose types (Fig. 4A). After sequencing the two 


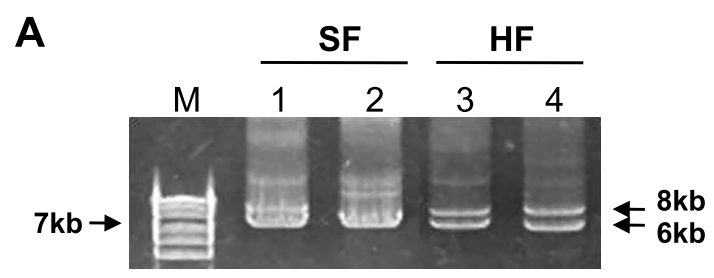

B



Fig. 4. Genomic structures of RoPI genes in Kurume azaleas. A: amplified PCR products from 5 ' upstream region to 3' UTR. M: HyperLadder $1 \mathrm{~kb}$ (Bioline, London, UK). SF: single flowers, 'Wakakaede' (1) and 'Oinomezame' (2). HF: hose-in-hose flowers, 'Kirin' (3) and 'Kurenoyuki' (4). B: Genomic structure of RoPI genes from 'Kirin'. Closed boxes show translated regions with exons and numerals above boxes indicate exon number. Open triangle indicates the position of the insertion sequence. Letters and closed triangles indicate target site duplication and terminal invert repeats, respectively.

PCR products in 'Kirin', we found that the length of RoPI-1 and RoPI-2 were 8033 bp (DDBJ accession number LC107400) and $5979 \mathrm{bp}$ (DDBJ accession number LC107401), respectively (Fig. 4B). In comparing these sequences, we found that RoPI-1 has an insertion sequence (1438 bp) in the second intron (Fig. 4B). The insertion sequence of RoPI-1 identified target site duplication (TSD; GTCTACAA) and terminal inverted repeats (TIR; right 5'-CATAGTTTTTAAT-3' and left 5'ATTTAAAACTATG-3'), but the inserted sequences showed no significant homology in BLASTx and BLASTn of GenBank. Furthermore, to confirm the insertion sequence of the RoPI mutant allele, we performed PCR amplification with primers designed based on the insertion sequence and its surrounding second and third exon sequences (P1, P2, P3, and P4 primers; Fig. 5A). A PCR product of $\mathrm{P} 1$ and $\mathrm{P} 2$ primer pair (approximately $730 \mathrm{bp}$ ), was amplified from both single and hose-in-hose flowers, whereas the PCR products of other pairs, such as P1 and P3 (approximately $580 \mathrm{bp}$ ) and P4 and P2 (approximately $470 \mathrm{bp}$ ), were amplified from only hose-in-hose flowers (Fig. 5B).

\section{Discussion}

This study was aimed to investigate the petaloid sepal development in hose-in-hose flower azalea at the morphological and molecular level. Microscopy and gene analysis studies were conducted to examine the
A

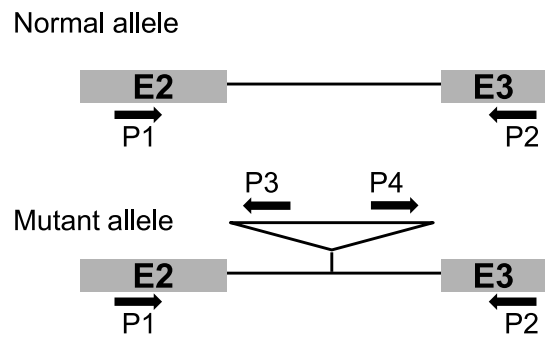

B

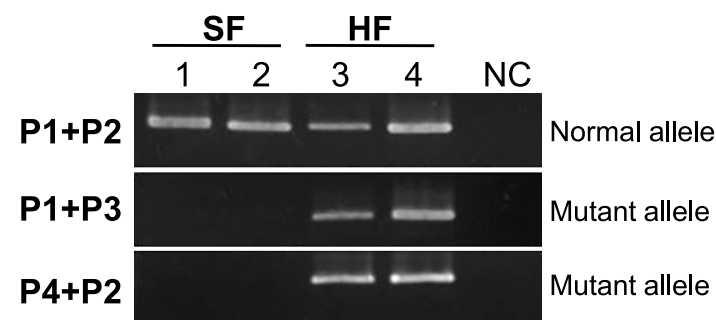

Fig. 5. PCR analysis of normal and mutant $R o P I$ alleles in single (SF) and hose-in-hose flower cultivars (HF). A: Schematic diagram showing primer regions to distinguish between normal and mutant alleles. E2, E3, closed arrow, and open triangle indicate second exon, third exon, primer direction, and inserted region, respectively. B: Results of PCR amplifications with designed primer pairs (A); SF: single flowers, 'Wakakaede' (1) and 'Oinomezame' (2). HF: hose-in-hose flowers, 'Kirin' (3) and 'Kurenoyuki' (4). NC indicates negative control. 
following hypotheses: the petaloid sepals of Kurume azalea in the first whorl show petal morphological characteristics, and the petaloid organ development in Kurume azalea is associated with MADS-box B-class gene regulation.

When we investigated the first whorl in single and hose-in-hose flowers, the first whorl of hose-in-hose flowers was similar to the petal morphology of the second whorl in both single and hose-in-hose flowers (Fig. 1). The hose-in-hose flower of Kurume azaleas is dominant to the single flower (Heursel, 1976; Sakata and Hashimoto, 2004). In morphological and genetic analysis of non-transgenic hose-in-hose plants, Habenaria radiata 'Ginga' has a flower with greenish sepals and white lateral petals and lip. Habenaria radiata 'Hishou' is a floral homeotic mutant with a petaloid median sepal and lip-like lateral sepals in the first whorl (Kanno and Kim, 2009; Kim et al., 2007). The characteristics of a petaloid median sepal and liplike lateral sepals in the first whorl were dominant (Kim et al., 2010). The hose-in-hose flower from Primula vulgaris (sepals converted to petaloid sepals) is also dominant to the corresponding single flower (Webster and Grant, 1990). The morphological changes and genetic characteristics of the first whorl closely resemble homeotic B class gene mutants in model and horticulture plants.

In the case of non-transgenic hose-in-hose horticulture plants, GLO and DEF homologs were expressed in the first and second whorl (outer and inner tepals) of a tulip (Tulipa gesneriana; Kanno et al., 2003) and Alstroemeria ligtu (Hirai et al., 2007). Moreover, both $P v G l o$ and $P v D e f$ genes were expressed in the first and second whorl in Primula hose-in-hose flower (Li et al., 2010). In transgenic Arabidopsis (Krizek and Meyerowitz, 1996a), p35S-PI plant flowers showed a conversion of sepals to petaloid sepals, with both sepal and petal tissue in the first whorl. In transgenic tobacco flowers (Davies et al., 1996), only p35S-DEF tobacco plants showed no phenotypic consequences in the first whorl, while only p35S-GLO over-expressed tobacco plants showed a phenotypic change (incomplete petal) in the first whorl. These results indicate that $G L O$ alone is capable of partially inducing the developmental pathways leading to petal and stamen production with inheritance of hose-in-hose as a single dominant locus, whereas DEF is not (Davies et al., 1996). In this study, higher expression of RoPI genes was shown in the first whorl of hose-in-hose flowers than in the first whorl of single flowers, whereas RpAP3 showed consistent expression in all whorls of both single and hose-in-hose flowers (Fig. 3). Moreover, the RoPI mutant allele RoPI-1 was found only in hose-in-hose flowers (Fig. 5). In contrast to hose-in-hose flowers, RpAP3 and RoPI were weakly expressed in the first whorl (Fig. 3), but the sepal was not converted to a petaloid sepal in single flowers (Fig. 1). This suggests that the expression level of RoPI may be important for petal or petaloid sepal formation in the first whorl of hose-in-hose Kurume azaleas.

Up-regulation of RoPI expression of hose-in-hose flower 'Kirin' has similarities to the work of $\mathrm{Li}$ et al. (2010), who reported that $P v G l o$ co-segregates with the hose-in-hose phenotype and characterized a retrotransposon insertion in the $P v G l o$ promoter, which is associated with up-regulated expression of $P v G l o$ in the first whorl. In this study, an unknown inserted sequence was found in the second intron, and the RoPI gene of the Kurume azalea showed the mutant allele in hose-inhose flowers but not in single flowers (Fig. 5). The results suggest that an inserted sequence in RoPI-1 may be important for the up-regulation of expression in the first whorl of hose-in-hose flowers. Interestingly, in the hose-in-hose Kurume azaleas, both RoPI-1 and -2 were expressed in the first whorl of 'Kirin' (Fig. 3A), whereas an insertion mutation was detected only in RoPI-1 during sequencing analysis of 'Kirin' gDNA (Fig. 4). A similar result has been reported for the ectopic expression of B function genes in tobacco (Davies et al., 1996). NTGLO, which is the $G L O$ homolog of tobacco, is not expressed in the first whorl of the wild-type flower and $N T D E F$, which is the $D E F$ homolog of tobacco, is expressed in all whorls of the wild-type flower. However, NTGLO expression is seen in the first whorl of p35S- $G L O$ and $\mathrm{p} 35 \mathrm{~S}-D E F / \mathrm{p} 35 \mathrm{~S}-G L O$ plants that have conversion of sepal to petal tissue. As in tobacco, because RpAP3 expression is shown in all whorls of single and hose-in-hose flowers, $R o P I-2$ expression may be controlled by the mutant allele, RoPI-1, although more experiments will be needed to clarify the relationship between the RoPI genes.

In conclusion, the horticulturally important trait "hose-in-hose", which is derived from wild evergreen azaleas in Japan, is caused by the expansion of $P I$ gene expression in the first whorl. However, azalea PI/GLO homolog regulation, such as petal or petaloid-like organ formation in the first whorl, remains to be clarified. In the future, we will analyze the relationship among a number of RoPI alleles, transposable element-like sequences, and RoPI expression levels using other cultivars and $F_{1}$ hybrid plants. Moreover, to select hose-inhose flowers at a young stage, we will develop genebased markers using the RoPI mutant allele for efficient azalea breeding.

\section{Literature Cited}

Cheon, K.-S., A. Nakatsuka and N. Kobayashi. 2011. Isolation and expression pattern of genes related to flower initiation in the evergreen azalea, Rhododendron $\times$ pulchrum 'Oomurasaki'. Sci. Hortic. 130: 906-912.

Coen, E. S. and E. M. Meyerowitz. 1991. The war of the whorls: genetic interactions controlling flower development. Nature 353: 31-37.

Davies, B., A. Di Rosa, T. Eneva, H. Saedler and H. Sommer. 1996. Alteration of tobacco floral organ identity by expres- 
sion of combinations of Antirrhinum MADS-box genes. Plant J. 10: 663-677.

Heursel, J. 1976. Die Vererbung des Merkmals "hose in hose" (Doppelkronigkeit) bei Azaleen. Gartenwelt 76: 111-113 (In German).

Hirai, M., T. Kamimura and A. Kanno. 2007. The expression patterns of three class B genes in two distinctive whorls of petaloid tepals in Alstroemeria ligtu. Plant Cell Physiol. 48: 310-321.

Kanno, A. and S. Y. Kim. 2009. Morphological differentiation of sepal and petal in Habenaria radiata (Orchidaceae). p. 313323. In: N. Huttunen and T. Sinisalo (eds.). Plant Breeding (Agronomy research and developments series). Nova Science Publishers, Inc., New York.

Kanno, A., H. Saeki, T. Kameya, H. Saedler and G. Theissen. 2003. Heterotopic expression of class B floral homeotic genes supports a modified $\mathrm{ABC}$ model for tulip (Tulipa gesneriana). Plant Mol. Biol. 52: 831-841.

Kim, S.-Y., M. Endo, P.-Y. Yun and A. Kanno. 2010. Production of intraspecific hybrids between wild-type and petaloidsepal cultivars in Habenaria radiate. Sci. Hortic. 124: 415418.

Kim, S.-Y., P.-Y. Yun, T. Fukuda, T. Ochiai, J. Yokoyama, T. Kameya and A. Kanno. 2007. Expression of a DEFICIENS like gene correlates with the differentiation between sepal and petal in the orchid, Habenaria radiata (Orchidaceae). Plant Sci. 172: 319-326.

Kobayashi, N., T. Handa, K. Takayanagi and K. Arisumi. 2003. Clarification of origin in azalea cultivars by PCR-RFLP analysis of chloroplast DNA. J. Jpn. Soc. Agric. Technol. Manage. 10: 143-147 (In Japanese with English abstract).

Kobayashi, N., T. Horikoshi, H. Katsuyama, T. Handa and K. Takayanagi. 1998. A simple and efficient DNA extraction method from the plants, especially from woody plants. Plant Tiss. Cult. Biotech. 4: 76-80.

Kramer, E. M., R. L. Dorit and V. F. Irish. 1998. Molecular evolution of genes controlling petal and stamen development: duplication and divergence within the APETALA3 and PISTILLATA MADS-Box gene lineages. Genetics 149: 765783.

Krizek, B. A. and E. M. Meyerowitz. 1996a. The Arabidopsis homeotic genes APETALA3 and PISTILLATA are sufficient to provide the $\mathrm{B}$ class organ identity function. Development 122: $11-22$

Krizek, B. A. and E. M. Meyerowitz. 1996b. Mapping the protein regions responsible for the functional specificities of the Arabidopsis MADS domain organ-identity proteins. Proc. Natl. Acad. Sci. USA 93: 4063-4070.

Li, J., B. Dudas, M. A. Webster, H. E. Cook, B. H. Davies and P. M. Gilmartin. 2010. Hose in Hose, an S locus-linked mutant of Primula vulgaris, is caused by an unstable mutation at the Globosa locus. Proc. Natl. Acad. Sci. USA 107: 56645668.

Miyazawa, B. 1922. On the 'Kirishima-tsutsuzi'. Jpn. J. Genet. 1: 150-157 (In Japanese).

Ochman, H., A. S. Gerber and D. L. Hart. 1988. Genetic applications of an inverse polymerase chain reaction. Genetics 120 : 621-623.

Riechmann, J. L. and E. M. Meyerowitz. 1997. Determination of floral organ identity by Arabidopsis MADS domain homeotic proteins AP1, AP3, PI, and AG is independent of their DNA-binding specificity. Mol. Biol. Cell 8: 1243-1259.

Sakata, Y. and F. Hashimoto. 2004. Method of breeding azalea. Japan patent WO2005009116 A1.

Tamura, T., S. Yamaguchi, S. Annou, S. Hisatomi, T. Matsuno, M. Terasaki and K. Nakano. 1989. Azaleas in Kurume: Monograph of Kurume azalea and its relatives. Ashishobou, Fukuoka.

Tasaki, K., A. Nakatsuka, K.-S. Cheon, M. Koga and N. Kobayashi. 2012. Morphological and expression analyses of MADS genes in Japanese traditional narrow- and/or staminoid-petaled cultivars of Rhododendron kaempferi Planch. Sci. Hortic. 134: 191-199.

Webster, M. A. and C. J. Grant. 1990. The inheritance of calyx morph variants in Primula vulgaris (Huds.). Heredity 64: 121-124.

Weigel, D. and E. M. Meyerowitz. 1994. The ABCs of floral homeotic genes. Cell 78: 203-209.

Wilson, E. H. and A. Rehder. 1921. A Monograph of Azaleas: Rhododendron subgenus Anthodendron. University Press, Cambridge, MA. 